\title{
Nutrient omission effect on growth and nutritional status of assai palm seedlings ${ }^{1}$
}

\author{
Fábio Reis Ribeiro Araújo ${ }^{2}$, Ismael de Jesus Matos Viégas ${ }^{3}$, \\ Raimundo Lázaro Moraes da Cunha ${ }^{4}$, Werica Larissa Farias de Vasconcelos ${ }^{2}$
}

\section{ABSTRACT}

The Amazonian assai palm has a great socioeconomic importance, but most of its commercial plantations take place in uplands and low natural fertility soils, what may hinder its development. This study aimed at evaluating the effect of nutrient omission on growth and nutritional status of assai palm seedlings (Ver-o-Peso cultivar). The experimental design was completely randomized, with 14 treatments and 5 replicates. The treatments consisted of complete fertilization with liming; no fertilization and no liming (control); complete fertilization with individual omission of $\mathrm{N}, \mathrm{P}, \mathrm{K}, \mathrm{Ca}, \mathrm{Ca}$ with no liming, $\mathrm{Mg}, \mathrm{Mg}$ with no liming, $\mathrm{S}, \mathrm{B}, \mathrm{Cu}$ and $\mathrm{Zn}$. Plant height, stem diameter and dry mass, leaf and total shoot dry mass, and leaf nutrients content and accumulation were evaluated. The initial growth of the assai palm plants was limited by the omission of $\mathrm{P}, \mathrm{N}, \mathrm{K}, \mathrm{Ca}, \mathrm{Mg}$ and $\mathrm{Cu}$. The production of leaf dry mass was decreasingly affected by the omission of $\mathrm{P}>\mathrm{Cu}>\mathrm{N}>\mathrm{K}>\mathrm{Mg}$, while leaf area was limited by the individual omissions of $\mathrm{Ca}>\mathrm{N}>\mathrm{P}>\mathrm{K}>\mathrm{Mg}>\mathrm{Zn}$. Plant development, measured by relative growth of shoots, was affected by lack of $\mathrm{Ca}>\mathrm{P}>\mathrm{N}>\mathrm{Mg}>\mathrm{Cu}>\mathrm{K}$, with an average reduction of $31 \%$. The nutrients most needed by the assai palm plants, as evidenced by nutrients contents and accumulation in the leaf dry mass, are: $\mathrm{N}>\mathrm{K}>\mathrm{S}>\mathrm{Ca}>$ $\mathrm{Mg}>\mathrm{P}>\mathrm{Mn}>\mathrm{Zn}>\mathrm{B}>\mathrm{Cu}$.

KEYWORDS: Euterpe oleracea Mart.; palm tree; plant nutrition.

\section{INTRODUCTION}

Assai palm (Euterpe oleracea Mart.) is native from Amazonia, being abundant in the estuary of the Amazon River, in lowland and flooded forest areas. The main product of the assai palm is its fruit, which is basically consumed in natura in juices. It is also an economic alternative for the production of heart of palm, because of its multi-stemmed clump growth

\section{RESUMO}

Efeito da omissão de nutrientes no crescimento e estado nutricional de mudas de açaizeiro

O açaizeiro é uma palmeira amazônica de grande importância socioeconômica, mas a maioria de seus plantios comerciais ocorre em terras firmes e de baixa fertilidade natural, o que pode causar diminuição em seu desenvolvimento. Objetivou-se avaliar o efeito da omissão de nutrientes no crescimento e estado nutricional de mudas de açaizeiro (cultivar Ver-o-Peso). O delineamento experimental foi inteiramente casualizado, com 14 tratamentos e 5 repetições. Os tratamentos consistiram de adubação completa com calagem; sem adubação e sem calagem (testemunha); adubação completa com omissões individuais de $\mathrm{N}, \mathrm{P}, \mathrm{K}, \mathrm{Ca}, \mathrm{Ca}$ sem calagem, $\mathrm{Mg}, \mathrm{Mg}$ sem calagem, S, B, Cu eZn. Foram avaliados a altura das plantas, diâmetro e massa seca do caule, massa seca das folhas e aérea total, teores e acúmulo de nutrientes nas folhas. $\mathrm{O}$ crescimento inicial dos açaizeiros foi limitado pela omissão de $\mathrm{P}, \mathrm{N}, \mathrm{K}, \mathrm{Ca}, \mathrm{Mg}$ e Cu. A produção de massa seca das folhas foi afetada em ordem decrescente pela omissão de $\mathrm{P}>$ $\mathrm{Cu}>\mathrm{N}>\mathrm{K}>\mathrm{Mg}$, enquanto a área foliar foi restringida por omissões individuais de $\mathrm{Ca}>\mathrm{N}>\mathrm{P}>\mathrm{K}>\mathrm{Mg}>\mathrm{Zn}$. O desenvolvimento das plantas, medido pelo crescimento relativo da parte aérea, foi afetado pela carência de $\mathrm{Ca}>\mathrm{P}>\mathrm{N}>\mathrm{Mg}>\mathrm{Cu}>\mathrm{K}$, com redução média de $31 \%$. Os nutrientes mais exigidos pelos açaizeiros, evidenciados pelos teores e acúmulos de nutrientes na massa seca das folhas, são: $\mathrm{N}>\mathrm{K}>\mathrm{S}>\mathrm{Ca}>\mathrm{Mg}>\mathrm{P}>\mathrm{Mn}>\mathrm{Zn}>\mathrm{B}>\mathrm{Cu}$.

PALAVRAS-CHAVE: Euterpe oleracea Mart.; palmeira; nutrição vegetal.

habit, making its continued exploitation viable, when managed rationally (Menezes et al. 2008).

In 2015, the national production of assai fruit, in Brazil, totaled more than one million tons, with the main producer being the Pará State $(91.6 \%)$, which reached 154,000 ha (IBGE 2015). In 2016, Embrapa Amazônia Oriental will launch the assai palm BRS Ver-o-Peso cultivar, which is destined for planting in irrigated upland, and will be able to produce off

1. Manuscript received in Apr./2016 and accepted for publication in Oct./2016 (http://dx.doi.org/10.1590/1983-40632016v4640770). 2. Universidade Federal do Sul e Sudeste do Pará, Instituto de Estudos em Desenvolvimento Agrário e Regional, Faculdade de Ciências Agrárias, Marabá, PA, Brazil.E-mails: fabioaraujo@unifesspa.edu.br,werica_lee@hotmail.com.

3. Universidade Federal Rural da Amazônia, Campus Capanema, Capanema, PA, Brazil.E-mail: ismael.viegas@ufra.edu.br. 4. Universidade Federal Rural da Amazônia, Campus Belém, Belém, PA, Brazil. E-mail: cunhalazaro@yahoo.com.br. 
season fruits with a higher yield than the BRS Pará cultivar.

Assai palm naturally occurs in lowlands, which are ecosystems with eutrophic, acidic, clay-silty soils and a good natural fertility, due to depositions of sediments brought in by tides (Oliveira et al. 2007). These soils receive a regular contribution of various sediments rich in $\mathrm{N}, \mathrm{Ca}, \mathrm{P}, \mathrm{K}$ and $\mathrm{Mg}$ that are transported by the Amazon River and its tributaries from the Andean mountains (Almeida et al. 2004). However, the majority of assai palm commercial plantations are located in upland soils, where Ferralsols of low natural fertility dominate and the provision of nutrients through fertilization is necessary to achieve high yields (Viégas et al. 2004).

Palms require high levels of nutrients for both vegetative growth and reproduction. In addition, an adequate supply of fertilizer is necessary to promote a greater initial growth (Bovi et al. 2002). Experiments with fertility may help to determine which nutrients are most limiting to plant development (Lopes 2001, Viégas et al. 2004). The first research on assai palm nutrition emphasized that macronutrients interfere with the production of total dry matter by young plants in the following order: $\mathrm{K}>\mathrm{Mg}>\mathrm{P}>\mathrm{N}>\mathrm{Ca}>\mathrm{S}$ (Haag et al. 1992, Oliveira et al. 2002).

Nutritional disorders cause a decrease in the development and production of any crop, and commonly manifested visual symptoms tend to be more pronounced in the leaves. However, yield may often be compromised even before symptoms occur (Malavolta 1980). In this context, the missing element technique evaluates the nutritional requirements of crops and is an effective tool for acquiring qualitative information on the nutrients that most limit plant growth (Laviola \& Dias 2008, Miranda et al. 2010).

Thus, the present study aimed at evaluating the growth, dry mass production and content and accumulation of macro and micronutrients in assai palm seedlings (BRS Ver-o-Peso cultivar), using a sandy-textured Ferralsol substrate under the effect of individual nutrients omission.

\section{MATERIAL AND METHODS}

The experiment was conducted under greenhouse conditions at the Universidade Federal Rural da Amazônia, in Belém, Pará State, Brazil, from September 2013 to April 2014. The substrate used was a sandy-textured Ferralsol (FAO 2015),
"Latossolo Amarelo" in the Brazilian system (Embrapa 2013), collected in Belém, at a depth of $0-30 \mathrm{~cm}$, which has low natural fertility and is deep and well drained.

Prior to the experiment, a physico-chemical analysis of the soil was performed (Embrapa 1997), resulting in the following profile: clay $=11 \%$; silt $=$ $6 \%$; sand $=83 \% ; \mathrm{pH}\left(\mathrm{H}_{2} \mathrm{O}\right)=4.8 ; \mathrm{P}=25.28 \mathrm{mg} \mathrm{dm}^{-3}$; $\mathrm{K}=20.3 \mathrm{mg} \mathrm{dm}^{-3} ; \mathrm{Ca}=0.70 \mathrm{cmol}_{\mathrm{c}} \mathrm{dm}^{-3} ; \mathrm{Mg}=$ $0.10 \mathrm{cmol}_{\mathrm{c}} \mathrm{dm}^{-3} ; \mathrm{S}=6.8 \mathrm{mg} \mathrm{dm}{ }^{-3} ; \mathrm{Al}=0.70 \mathrm{cmol}_{\mathrm{c}} \mathrm{dm}^{-3}$; $\mathrm{H}+\mathrm{Al}=6.30 \mathrm{cmol} \mathrm{dm}^{-3} ; \mathrm{B}=0.33 \mathrm{mg} \mathrm{dm}^{-3} ; \mathrm{Cu}=$ $0.89 \mathrm{mg} \mathrm{dm}^{-3} ; \mathrm{Mn}=3.6 \mathrm{mg} \mathrm{dm}^{-3} ; \mathrm{Zn}=1.41 \mathrm{mg} \mathrm{dm}^{-3}$; $\mathrm{V}(\%)=11.9 ; \mathrm{OM}=23.6 \mathrm{~g} \mathrm{~kg}^{-1} ; \mathrm{SB}=0.85 \mathrm{cmol}_{\mathrm{c}} \mathrm{dm}^{-3}$. The high levels of $\mathrm{P}$ indicate that the soil had been previously fertilized.

The $\mathrm{pH}\left(\mathrm{H}_{2} \mathrm{O}\right)$ was determined using a glass electrode placed in a 1:2.5 soil to liquid suspension. The amounts of $\mathrm{Ca}$ and $\mathrm{Mg}$ were measured by atomic absorption, after their extraction with $\mathrm{KCl}$ at $1 \mathrm{~N}$; $\mathrm{P}$ was extracted with a solution of $\mathrm{H}_{2} \mathrm{SO}_{4}+\mathrm{HCl} 0.025 \mathrm{~N}$ and measured with a spectrophotometer (wavelength of $660 \mathrm{~nm}$ ); K was determined by flame photometry and $\mathrm{Al}$ by titration with $\mathrm{NaOH} 0.025 \mathrm{~N}$.

The experimental design was completely randomized, with 14 treatments and 5 replicates, with each container corresponding to one experimental unit. The treatments were: complete (complete fertilization with all the nutrients plus liming); control (without fertilization and without liming); complete fertilization with liming and omission of nitrogen $(-\mathrm{N})$, phosphorus (-P), potassium (-K), calcium (-Ca), calcium without liming (-Ca/-lime), magnesium $(-\mathrm{Mg})$, magnesium without liming (-Mg/-lime), sulfur $(-\mathrm{S})$, boron (-B), copper (-Cu), manganese (-Mn) and zinc $(-\mathrm{Zn})$.

Liming was performed using the base saturation method, aiming to raise the base saturation up to $60 \%$ (Cravo et al. 2010), applying dolomitic limestone with $32 \%$ of $\mathrm{CaO}, 14 \%$ of $\mathrm{MgO}, 67 \%$ of $\mathrm{NP}$ and relative power of total neutralization of $95 \%$. The lime was homogeneously mixed with the substrate and incubated for 30 days.

Seedlings were produced using seeds of the new assai palm BRS Ver-o-Peso cultivar, developed by the Embrapa Amazônia Oriental. The seeds were sown in seedbeds containing a mixture of black earth, sawdust and aged cattle manure in the proportion of $3: 1: 1$. When seedlings reached an average height of $10 \mathrm{~cm}$ and showed one pair of leaves, they were transplanted in pairs into plastic containers with $5 \mathrm{~kg}$ 
of air-dried fine earth that had been previoulsy sieved (4 mm mesh).

At 45 days after planting, the seedlings were thinned for homogenization and all containers were provided with mineral fertilization, according to their designated treatments. Fertilization was performed according to Viégas et al. (2009), with the following doses, taking into account the missing element technique: $\mathrm{N}=100 \mathrm{mg} \mathrm{kg}^{-1}\left[-\mathrm{CO}\left(\mathrm{NH}_{2}\right)_{2}\right]$; $\mathrm{P}=50 \mathrm{mg} \mathrm{kg}^{-1}\left(-\mathrm{NaH}_{2} \mathrm{PO}_{4}\right) ; \mathrm{K}=90 \mathrm{mg} \mathrm{kg}^{-1}(-\mathrm{KCl})$; $\mathrm{Ca}=30 \mathrm{mg} \mathrm{kg}^{-1}\left(-\mathrm{CaCl}_{2}\right) ; \mathrm{Mg}=30 \mathrm{mg} \mathrm{kg}^{-1}\left(-\mathrm{MgCl}_{2}\right)$; $\mathrm{S}=7.5 \mathrm{mg} \mathrm{kg}^{-1}\left(-\mathrm{NaSO}_{4}\right) ; \mathrm{B}=1.2 \mathrm{mg} \mathrm{kg}^{-1}\left(-\mathrm{H}_{3} \mathrm{BO}_{3}\right)$; $\mathrm{Cu}=1.0 \mathrm{mg} \mathrm{kg}^{-1}\left(-\mathrm{CuSO}_{4}\right) ; \mathrm{Mn}=4 \mathrm{mg} \mathrm{kg}^{-1}\left(-\mathrm{MnSO}_{4}\right)$; and $\mathrm{Zn}=5 \mathrm{mg} \mathrm{kg}^{-1}\left(-\mathrm{ZnSO}_{4}\right)$ of soil.

A fertilizer containing $\mathrm{N}$ and $\mathrm{K}$ was applied at 45, 90 and 150 days after planting. The soil was irrigated with distilled water, while weighing the pots to maintain substrates at $80 \%$ of field capacity. Plant height, stem diameter at $2.5 \mathrm{~cm}$ from the substrate and leaf number and size (length and width of leaflets) were measured.

Plants were collected at eight months after planting the seedlings, separating the leaflets, petioles, stems and roots. The separate organs were packed in paper bags, identified and placed in a forced-circulation oven at $70{ }^{\circ} \mathrm{C}$, until a constant mass was reached, at which point the dried material was weighed and ground in a Wiley mill, in order to determine the nutrient content. The shoot relative growth (SRG) was calculated as it follows: $\operatorname{SRG}(\%)=$ $(\mathrm{DMNO} / \mathrm{DMCT}) \times 100$, where $\mathrm{DMNO}=$ total shoot dry mass for each nutrient omission and DMCT $=$ total shoot dry mass for the complete treatment. Leaf area (LA) was calculated following an adaptation of the method by Clement \& Bovi (2000), as it follows: $\mathrm{LA}\left(\mathrm{m}^{2}\right)=(\mathrm{L} \times \mathrm{W}) \times 0.535$, where $\mathrm{L}=$ leaf length, $\mathrm{W}=$ leaf width and $0.535=$ constant adjusting the shape of a rectangle to the shape of a leaf. The determination of leaf macro and micronutrients was performed according to Embrapa (2010).

An analysis of variance (Anova) was performed on the data for the following variables: plant height, stem diameter, leaf and stem dry mass, and total content and accumulation of macro and micronutrients. To determine the accumulation of nutrients, the content $\left(\mathrm{g} \mathrm{kg}^{-1}\right)$ of each nutrient was multiplied by the leaf dry mass.

For variables significantly affected by the treatments, the Dunnett's test was used to compare the treatments means with that of the complete treatment, at $5 \%$. Analyses were performed using the Action ${ }^{\circledR}$ software.

\section{RESULTS AND DISCUSSION}

The results for plant height, stem height and diameter, shoot dry biomass, leaf area and relative shoot growth, according to the treatments, are shown in Table 1.

Nutrient omission treatments exhibited values for plant height and stem height and diameter less than, or equal to, that of the complete treatment. The absence of liming and fertilization in the control plants restricted plant height by $41.5 \%$, stem height by $45.2 \%$ and stem diameter by $36.5 \%$, in relation to the complete treatment. These results justify the importance of nutrients fertilization for the proper development of assai palm plants cultivated in sandytextured Ferralsol. Stem height and diameter for the control plants were the only estimates that differed significantly from the complete treatment.

The omissions of the macronutrients $\mathrm{N}$, $\mathrm{P}, \mathrm{K}, \mathrm{Ca} /$-lime, $\mathrm{Mg}$ and $\mathrm{Mg}$ /-lime were the most restricting to the initial growth of assai palm plants. The omission of these nutrients was responsible for an average decrease of $22.1 \%$ in plant height, relatively to the complete treatment, with $\mathrm{N}, \mathrm{P}$ and $\mathrm{K}$ decreasing the plant height by $20.3 \%, 23.3 \%$ and $20.3 \%$, respectively. These results corroborate Viégas et al. (2004), who found that the omission of N, P and $\mathrm{K}$ in medium-textured Ferralsol limited the plant height of assai palm (BRS Pará cultivar) by $35.4 \%$, $38.5 \%$ and $26 \%$, respectively. Viégas et al. (2009) also showed that the individual omission of N, P and $\mathrm{K}$ in Ferralsol limits the plant height of assai palm.

The omission of $\mathrm{Ca} /$-lime restricted plant height by $24.4 \%$, showing the importance of the joint practices of fertilization and liming. However, the effect of the absence of liming was not found with the individual omission of $\mathrm{Mg}$ and $\mathrm{Mg} /$-lime, which restricted plant height by $23.1 \%$ and $21.1 \%$, respectively. Viégas et al. (2008) indicated that the omission of $\mathrm{Mg}$ restricted the growth of assai palm seedlings by $50.8 \%$.

Regarding the micronutrients omission, only the omission of $\mathrm{Cu}$ showed a significant difference from the complete treatment, with a reduction of $20.3 \%$ in plant height. Viégas et al. (2004) recorded a reduction of $7.7 \%$ in plant height of assai palm with the omission of $\mathrm{Cu}$. 
For shoot dry biomass, all the treatments were less than, or equal to, the complete treatment (Table 1). The individual nutrients whose omission had the greatest restriction to leaf dry mass production, relatively to the complete treatment, were $\mathrm{P}$ with a reduction of $34.3 \%$; $\mathrm{N}$ with $32.5 \%$; $\mathrm{K}$ with $30.7 \%$; and $\mathrm{Mg}$ with $28.1 \%$. Regarding the omission of micronutrients, the only treatment with a significant difference was $\mathrm{Cu}$, with a reduction of $33.7 \%$ in leaf dry mass, if compared to the complete treatment. The control treatment restricted the leaf dry mass gain by $66.1 \%$.

For the stem dry mass production, the individual nutrients that were most restrictive when omitted were $\mathrm{N}, \mathrm{P}, \mathrm{Ca} /$-lime and $\mathrm{Mg} /$-lime, with reductions relatively to the complete treatment of $35.2 \%, 36.3 \%, 39.8 \%$ and $34.1 \%$, respectively. The other individual omissions did not exhibit significant differences, and the control experienced a decrease of $77.3 \%$ in stem dry mass.

For the shoot dry mass production, the omitted elements that limited mass gain, relatively to the complete treatment, were the same as those for stem dry mass: $\mathrm{N}, \mathrm{P}, \mathrm{Ca} /$-lime and $\mathrm{Mg}$ /-lime, with reductions of $33.3 \%, 34.5 \%, 37 \%$ and $24.8 \%$, respectively. The absence of fertilization and liming in the control treatment decreased the gain of shoot dry mass by $71.7 \%$.
Viégas et al. (2004) observed a decrease in leaf dry mass and stem and shoot dry mass, in assai palm plants, as an effect of the individual omission of N, P, $\mathrm{K}, \mathrm{Ca}$ and $\mathrm{Mg}$, relatively to the complete treatment. For leaves, the mass of the complete treatment was $51.4 \mathrm{~g}$, while the omissions of $\mathrm{N}, \mathrm{P}, \mathrm{K}$ and $\mathrm{Mg}$ reduced growth by $49.3 \%, 49 \%, 26.8 \%$ and $21.7 \%$, respectively. For stems, the omission of $\mathrm{N}$ reduced growth by $70.7 \%$, P by $74 \%$, K by $40.9 \%$, Ca by $39.6 \%$ and $\mathrm{Mg}$ by $24.6 \%$. For shoot dry mass, the omissions were responsible for a decrease of $58.98 \%$ in the absence of N, $60.21 \%$ for $\mathrm{P}, 33.15 \%$ for $\mathrm{K}$, $27.21 \%$ for $\mathrm{Ca}$ and $37.14 \%$ for $\mathrm{Mg}$.

Leaf area was restricted by the individual omission of the nutrients $\mathrm{N}, \mathrm{P}, \mathrm{K}$ and $\mathrm{Mg}$ by $40.6 \%, 39.2 \%, 35.9 \%$ and $37.6 \%$, respectively. The omission of $\mathrm{Zn}$ decreased leaf area by $35.8 \%$, relatively to the complete treatment. The control treatment had its leaf area reduced by $69 \%$. Viégas et al. (2008) showed that the number of leaves on assai palm plants, in treatments with individual omission of $\mathrm{N}, \mathrm{P}$ and $\mathrm{K}$, were reduced significantly (around $50 \%, 33 \%$ and $30 \%$, respectively), in relation to the complete treatment.

The shoot relative growth followed the descending order of complete $>\mathrm{Ca}>\mathrm{S}>\mathrm{B}>\mathrm{Zn}>$ $\mathrm{Mg}>\mathrm{Mn}>\mathrm{K}>\mathrm{Cu}>\mathrm{Mg}$ /-lime $>\mathrm{N}>\mathrm{P}>\mathrm{Ca} /$-lime $>$ control. Therefore, the development of the plant,

Table 1. Height (HT), stem height (SH), stem diameter (SD), leaf dry mass (LDM), stem dry mass (SDM), shoot dry mass (SHDM), leaf area (LA) and relative growth (RG) of assai palm, according to the treatment. Treatments: complete (complete fertilization with all nutrients and liming); control (without fertilization and without liming); complete fertilization with liming and omission of a nutrient represented by its chemical symbol $(-\mathrm{X})$; complete fertilization without liming and with nutrient omission represented by its chemical symbol (-X/-lime).

\begin{tabular}{|c|c|c|c|c|c|c|c|c|}
\hline \multirow{2}{*}{ Treatment } & HT & $\mathrm{SH}$ & \multirow{2}{*}{$\begin{array}{c}\mathrm{SD} \\
\mathrm{mm}\end{array}$} & LDM & SDM & SHDM & \multirow{2}{*}{$\begin{array}{c}\text { LA } \\
\mathrm{cm}^{2} \\
\end{array}$} & \multirow{2}{*}{$\begin{array}{c}\mathrm{RG} \\
\% \\
\end{array}$} \\
\hline & \multicolumn{2}{|c|}{$\mathrm{cm}$} & & & $\mathrm{g}-$ & $\bar{z}$ & & \\
\hline Complete & 72.00 & 22.00 & 16.85 & 9.53 & 33.62 & 43.15 & $1,776.72$ & 100.0 \\
\hline$-\mathrm{N}$ & $57.40 *$ & 18.40 & 15.38 & $6.43 *$ & $21.79 *$ & $28.76^{*}$ & $1,055.64 *$ & 65.4 \\
\hline$-\mathrm{P}$ & $55.20^{*}$ & 18.00 & 14.84 & $6.26^{*}$ & $21.40^{*}$ & $28.25^{*}$ & $1,079.61 *$ & 64.1 \\
\hline$-K$ & $57.40^{*}$ & 20.20 & 16.36 & $6.60 *$ & 25.94 & 34.34 & $1,139.37^{*}$ & 75.4 \\
\hline$-\mathrm{Ca}$ & 60.20 & 21.80 & 16.34 & 9.48 & 33.36 & 42.84 & $1,543.03$ & 99.3 \\
\hline -Ca/-lime & $54.40 *$ & 18.60 & 14.20 & 6.91 & $20.25^{*}$ & $27.17 *$ & $948.31 *$ & 63.0 \\
\hline$-\mathrm{Mg}$ & $55.40 *$ & 18.80 & 15.27 & $6.85^{*}$ & 29.27 & 39.12 & $1,108.63^{*}$ & 83.7 \\
\hline -Mg/-lime & $56.80 *$ & 19.00 & 16.19 & 8.37 & $22.15^{*}$ & $32.46^{*}$ & $1,322.22$ & 70.7 \\
\hline$-\mathrm{S}$ & 67.00 & 22.00 & 16.39 & 8.91 & 33.20 & 42.11 & $1,204.72$ & 97.6 \\
\hline$-\mathrm{Cu}$ & $57.40 *$ & 20.40 & 14.42 & $6.32 *$ & 26.11 & 41.79 & $1,254.77$ & 75.2 \\
\hline$-\mathrm{Zn}$ & 58.60 & 20.00 & 16.22 & 8.58 & 30.94 & 32.74 & $1,140.61 *$ & 91.6 \\
\hline$-\mathrm{Mn}$ & 60.40 & 20.80 & 16.18 & 7.64 & 27.48 & 35.12 & $1,196.98$ & 81.4 \\
\hline$-B$ & 62.80 & 20.60 & 16.20 & 9.00 & 31.99 & 39.52 & $1,239.26$ & 95.0 \\
\hline Control & $42.15^{*}$ & $12.05 *$ & $10.70 *$ & $3.23 *$ & $8.97 *$ & $12.20 *$ & $551.26^{*}$ & 28.3 \\
\hline CV (\%) & 11.50 & 13.50 & 9.30 & 19.63 & 22.97 & 21.50 & 28.82 & 25.1 \\
\hline
\end{tabular}

* Average significantly different from the complete treatment, in the same column, according to the Dunnett's test (p $<0.05)$. 
during the experimental period, was most affected by the total omission of nutrients in the control, with a reduction of $71.7 \%$. Phosphorus affected shoot relative growth the most, decreasing it by $35.9 \%$, followed by $\mathrm{N}$ with a $34.6 \%$ reduction, $\mathrm{Mg} /-$ lime with $29.3 \%$, Cu with $24.8 \%$ and $\mathrm{K}$ with $24.6 \%$.

The limitations to the development of assai palm seedlings, in the present study, may be explained by the low level of nutrients present in the substrate. Although the soil used displayed a satisfactory amount of $\mathrm{P}$, it had a low base saturation index $(\mathrm{V}=11.92 \%)$ and unsatisfactory amounts of $\mathrm{K}\left(20.28 \mathrm{mg} \mathrm{dm}^{-3}\right), \mathrm{Ca}\left(0.7 \mathrm{cmol}_{\mathrm{c}} \mathrm{dm}^{-3}\right)$ and $\mathrm{Mg}$ $\left(0.1 \mathrm{cmol}_{\mathrm{c}} \mathrm{dm}^{-3}\right)$. As observed by Cravo et al. (2010), the average concentrations of these elements for this crop in the Pará State are 41-60 mg dm${ }^{-3}$ for K, 0.5$1.5 \mathrm{cmol}_{\mathrm{c}} \mathrm{dm}^{-3}$ for $\mathrm{Ca}$ and $0.5-1.5 \mathrm{cmol}_{\mathrm{c}} \mathrm{dm}^{-3}$ for $\mathrm{Mg}$. The low levels of these elements may be considered limiting factors, in accordance with the Liebig's law (Malavolta 2006), as these low levels may restrict the absorption of other nutrients.

Thus, restrictions to growth and dry biomass gain caused by the omission of $\mathrm{N}, \mathrm{P}, \mathrm{K}, \mathrm{Ca}$ and $\mathrm{Mg}$, in this study, may be explained by the metabolic functions that result in plant biomass growth. Nitrogen is a constituent of the chlorophyll molecule, as well as various cell components, including proteins, amino acids and nucleic acids, and its deficiency alters the activity of enzymes from the biochemical phase of photosynthesis and from carbohydrate and nitrogen metabolism, thereby decreasing the rate of photosynthesis and thus the plant growth (Taiz \& Zeiger 2013). Phosphorus is a structural element of nucleotides and phospholipids, and it acts on the transfer of energy through phosphorus compounds (Cunha et al. 2009). Therefore, $P$ deficiency leads to lower growth by reducing the production and transport of energy.

The absence of $\mathrm{Mg}$ affects the size, structure and function of chloroplasts, since this element is a constituent of the chlorophyll molecule, in addition to activating enzymes involved in the processes of respiration, photosynthesis and nucleic acid synthesis (Taiz \& Zeiger 2013). Potassium acts in maintaining a favorable hydric system, among other functions, by osmotic stomatal regulation, influencing the transport and storage of carbohydrates, synthesis of proteins, enzyme activity and leaf starch synthesis (Armenguard et al. 2009).

The nutrient contents on the leaf dry mass of assai palms, for each treatment, are shown in Table 2.

In general, the treatments with omission of an individual nutrient caused a reduction in the content of that nutrient in the plant. In the leaf dry mass of the complete treatment, the descending sequence of contents for the different macronutrients was $\mathrm{N}>\mathrm{K}>$

Table 2. Levels of macro and micronutrients in the leaf dry matter of assai palm cultivated in sandy-textured Ferralsol, according to the treatment. Treatments: complete (fertilization with all nutrients and liming); control (without fertilization and without liming); complete fertilization with liming and omission of a nutrient represented by its chemical symbol (-X); complete fertilization without liming and with nutrient omission represented by its chemical symbol (-X/-lime).

\begin{tabular}{|c|c|c|c|c|c|c|c|c|c|c|}
\hline \multirow{3}{*}{ Treatment } & \multicolumn{10}{|c|}{ Content } \\
\hline & $\mathrm{N}$ & $\mathrm{P}$ & $\mathrm{K}$ & $\mathrm{Ca}$ & $\mathrm{Mg}$ & $\mathrm{S}$ & $\mathrm{Cu}$ & $\mathrm{Zn}$ & $\mathrm{Mn}$ & $\mathrm{B}$ \\
\hline & \multicolumn{6}{|c|}{$\mathrm{g} \mathrm{kg}^{-1}$} & \multicolumn{4}{|c|}{$\mathrm{mg} \mathrm{kg}^{-1}$} \\
\hline Complete & 24.14 & 1.25 & 14.52 & 2.61 & 2.19 & 7.39 & 7.22 & 93.17 & 99.93 & 54.45 \\
\hline$-\mathrm{N}$ & $12.88^{*}$ & $1.02 *$ & $9.50 *$ & $7.20 *$ & $3.04 *$ & $5.47 *$ & $4.08 *$ & $66.22 *$ & $76.66^{*}$ & 58.77 \\
\hline$-\mathrm{P}$ & 22.69 & $0.91 *$ & $9.62 *$ & 5.50 & 2.45 & 6.52 & $6.00 *$ & $60.15^{*}$ & $84.78 *$ & 60.21 \\
\hline$-K$ & 24.20 & 1.24 & $4.77 *$ & $6.44^{*}$ & $3.10^{*}$ & 6.47 & $5.14 *$ & $64.41 *$ & $83.75^{*}$ & $66.98 *$ \\
\hline$-\mathrm{Ca}$ & 24.27 & 1.19 & $11.67 *$ & $6.52 *$ & 2.98 & 4.50 & $4.43 *$ & $66.64 *$ & $71.33 *$ & 55.30 \\
\hline -Ca/-lime & 22.40 & 1.10 & 13.17 & 3.09 & 2.00 & 6.34 & $8.93 *$ & $100.34^{*}$ & $116.48^{*}$ & 50.54 \\
\hline$-\mathrm{Mg}$ & 21.98 & 1.25 & 9.86 & $5.49 *$ & 1.80 & $5.79 *$ & 6.21 & $71.51^{*}$ & 90.46 & 52.85 \\
\hline -Mg/-lime & 23.03 & 1.23 & 18.11 & 2.58 & $0.81 *$ & $5.13 *$ & 6.65 & $80.23 *$ & 109.62 & 55.71 \\
\hline$-\mathrm{S}$ & $21.21^{*}$ & 1.19 & 9.50 & $7.34 *$ & $3.04 *$ & 6.48 & $5.23 *$ & $62.71 *$ & $84.13 *$ & 54.95 \\
\hline$-\mathrm{Cu}$ & 22.78 & 1.18 & 13.05 & $7.05^{*}$ & $3.16^{*}$ & $5.65^{*}$ & $5.09 *$ & $59.17 *$ & $82.80 *$ & 54.09 \\
\hline$-\mathrm{Zn}$ & $18.74 *$ & 1.11 & $8.98^{*}$ & $6.54 *$ & 2.65 & $3.02 *$ & $5.17 *$ & $34.11 *$ & 89.31 & 54.88 \\
\hline$-\mathrm{Mn}$ & 23.31 & 1.21 & 11.55 & $7.18 *$ & 2.88 & $5.68 *$ & 6.23 & $64.40 *$ & $34.66^{*}$ & 46.51 \\
\hline$-B$ & 22.84 & 1.24 & 13.29 & $6.68^{*}$ & 2.86 & 6.85 & $5.99 *$ & $53.65^{*}$ & 95.28 & $17.47 *$ \\
\hline Control & $15.72 *$ & $0.80 *$ & $4.48 *$ & $7.06^{*}$ & $2.29 *$ & $4.77 *$ & $4.25 *$ & $31.03 *$ & $34.26^{*}$ & $32.21 *$ \\
\hline $\mathrm{CV}(\%)$ & 10.21 & 11.60 & 25.74 & 19.40 & 15.14 & 10.22 & 7.73 & 9.09 & 10.47 & 23.30 \\
\hline
\end{tabular}

* Average significantly different from the complete treatment, in the same column, by the Dunnett's test $(\mathrm{p}<0.05)$. 
$\mathrm{S}>\mathrm{Ca}>\mathrm{Mg}>\mathrm{P}$, while for the micronutrients it was $\mathrm{Mn}>\mathrm{Zn}>\mathrm{B}>\mathrm{Cu}$ (Table 3). Fernandes et al. (2013) concluded that, for the peach palm (Bactris gasipaes Kunth) grown in a complete solution, the descending sequence of macronutrient concentration in the leaves and stems was $\mathrm{N}>\mathrm{K}>\mathrm{Ca}>\mathrm{P}>\mathrm{Mg}>\mathrm{S}$.

The content of $\mathrm{N}$ in the leaf dry mass of the complete treatment was $24.14 \mathrm{~g} \mathrm{~kg}^{-1}$, a value higher than those found in similar experiments with assai palm in a Ferralsol: $15.67 \mathrm{~g} \mathrm{~kg}^{-1}$ (Viégas et al. 2009); $19.39 \mathrm{~g} \mathrm{~kg}^{-1}$ (Gonçalves 2004); and $16.6 \mathrm{~g} \mathrm{~kg}^{-1}$ (Haag et al. 1992).

The absorption of $\mathrm{N}$ was limited by the omission of $\mathrm{S}$ and $\mathrm{Zn}(16.3 \%$ and $22.9 \%$ lower than the full treatments, respectively), whereas lower values of absorption were obtained for the treatments omitting $\mathrm{N}$, with a reduction of $47.6 \%$ in $\mathrm{N}$ levels, and the control with $34.9 \%$ less $\mathrm{N}$. The decrease in the level of $\mathrm{N}$, as a result of the omission of $\mathrm{S}$, is related to the decrease in the sugar content, accumulation of carbohydrates and protein synthesis (Hawkesford 2000), because of the low conversion of $\mathrm{N}$ to an organic form (Prado et al. 2007).

The content of $\mathrm{P}$ obtained in the present study $\left(1.25 \mathrm{~g} \mathrm{~kg}^{-1}\right)$, in the complete treatment, is consistent with those observed by Haag et al. (1992) $\left(1.3 \mathrm{~g} \mathrm{~kg}^{-1}\right)$ and Gonçalves (2004) (1.69 $\left.\mathrm{g} \mathrm{kg}^{-1}\right)$. Phosphorus was limited by the omission of $\mathrm{N}, \mathrm{P}$ and $\mathrm{Ca}$-lime
(18.08\%, $27.2 \%$ and $11.36 \%$ lower than the complete treatment, respectively). The omission of all nutrients reduced the content of $\mathrm{P}$ by $35.68 \%$, since the absorption of $\mathrm{P}$ in low proportion was favored by the omission of $\mathrm{Mg}$.

The content of $\mathrm{K}\left(14.52 \mathrm{~g} \mathrm{~kg}^{-1}\right)$ obtained in the complete treatment is four times higher than that obtained by Viégas et al. (2009) (3.52 $\left.\mathrm{g} \mathrm{kg}^{-1}\right)$, but comparable with the results by Haag et al. (1992) $\left(19.6 \mathrm{~g} \mathrm{~kg}^{-1}\right)$ and Gonçalves (2004) $\left(9.42 \mathrm{~g} \mathrm{~kg}^{-1}\right)$, with both using a nutrient solution with a silica substrate.

The $\mathrm{K}$ content was limited by the omissions of control $>\mathrm{K}>\mathrm{N}>\mathrm{Zn}>\mathrm{P}>\mathrm{Mg}$. The level of $\mathrm{K}$ in the control was $69.2 \%$ lower, if compared to the complete treatment. The omission of $\mathrm{K}$ from the soil favored the absorption of Ca by the assai palms, what may be related to the competitive inhibition between both nutrients in the absorption process (Malavolta et al. 1997).

The content of $\mathrm{Ca}$ obtained in the complete treatment was statistically greater than all the omissions by an average of $160 \%$. It is believed that the high absorption of Ca may have been enhanced by the supplementation of this element via soil liming with dolomitic limestone, in the majority of treatments.

The leaf content of $\mathrm{Mg}$ obtained in the complete treatment $\left(2.19 \mathrm{~g} \mathrm{~kg}^{-1}\right)$ is comparable to

Table 3. Accumulation of macro and micronutrients in leaf dry material of assai palm cultivated in sandy-textured Ferralsol, according to the treatments. Treatments: complete (fertilization with all nutrients and liming); control (without fertilization and without liming); complete fertilization with liming and the omission of a nutrient represented by its chemical symbol (-X); complete fertilization without liming and with nutrient omission represented by its chemical symbol (-X/-lime).

\begin{tabular}{|c|c|c|c|c|c|c|c|c|c|c|}
\hline \multirow{2}{*}{ Treatment } & \multicolumn{10}{|c|}{ Accumulation (mg plant $\left.{ }^{-1}\right)$} \\
\hline & $\mathrm{N}$ & $\mathrm{P}$ & $\mathrm{K}$ & $\mathrm{Ca}$ & $\mathrm{Mg}$ & $\mathrm{S}$ & $\mathrm{Cu}$ & $\mathrm{Zn}$ & $\mathrm{Mn}$ & $\mathrm{B}$ \\
\hline Complete & 229.51 & 11.85 & 138.71 & 24.79 & 20.76 & 70.74 & 0.068 & 0.884 & 0.973 & 0.517 \\
\hline$-\mathrm{N}$ & $92.09 *$ & $7.20 *$ & $65.65^{*}$ & 49.77 & 21.19 & $37.91 *$ & $0.029^{*}$ & $0.460^{*}$ & $0.533^{*}$ & 0.409 \\
\hline$-\mathrm{P}$ & $156.46^{*}$ & $6.08 *$ & $65.74 *$ & 37.17 & 16.63 & $44.53^{*}$ & $0.042 *$ & $0.411^{*}$ & $0.579^{*}$ & 0.413 \\
\hline$-K$ & 202.21 & 10.39 & $41.09 *$ & $54.81^{*}$ & 26.24 & 54.33 & $0.043^{*}$ & $0.540^{*}$ & 0.704 & 0.564 \\
\hline$-\mathrm{Ca}$ & 234.70 & 11.59 & 108.33 & $62.75^{*}$ & 28.86 & $43.49 *$ & $0.043^{*}$ & $0.638^{*}$ & 0.689 & 0.537 \\
\hline -Ca/-lime & $155.81^{*}$ & $7.65^{*}$ & $87.75^{*}$ & 20.35 & 13.55 & $43.88^{*}$ & 0.060 & 0.691 & 0.780 & 0.351 \\
\hline$-\mathrm{Mg}$ & 215.14 & 12.23 & 96.60 & $56.02 *$ & 17.39 & 57.29 & 0.061 & 0.709 & 0.895 & 0.522 \\
\hline -Mg/-lime & 192.62 & 10.29 & 152.85 & 21.67 & $6.81^{*}$ & $42.90 *$ & 0.056 & 0.675 & 0.919 & 0.466 \\
\hline$-\mathrm{S}$ & 190.10 & 10.69 & $84.12^{*}$ & $65.51 *$ & 27.38 & 57.74 & $0.046^{*}$ & $0.560^{*}$ & 0.746 & 0.489 \\
\hline$-\mathrm{Cu}$ & $150.14 *$ & $7.81 *$ & 89.33 & 46.03 & 20.87 & $37.44 *$ & $0.034^{*}$ & $0.392 *$ & $0.548^{*}$ & 0.360 \\
\hline$-\mathrm{Zn}$ & 159.73 & 9.52 & $75.86^{*}$ & $55.55^{*}$ & 22.44 & $25.87 *$ & $0.044^{*}$ & $0.291^{*}$ & 0.764 & 0.471 \\
\hline -Mn & 176.69 & 9.15 & 90.21 & $54.65^{*}$ & 21.91 & $43.10^{*}$ & $0.048^{*}$ & $0.496^{*}$ & $0.265^{*}$ & 0.355 \\
\hline$-B$ & 223.44 & 12.17 & 130.16 & $65.38^{*}$ & 27.99 & 67.01 & 0.058 & $0.527 *$ & 0.933 & $0.172 *$ \\
\hline Control & $51.36^{*}$ & $2.52 *$ & $15.24 *$ & $23.57 *$ & $7.55^{*}$ & $17.38^{*}$ & $0.014 *$ & $0.100 *$ & $0.109^{*}$ & $0.111^{*}$ \\
\hline CV (\%) & 22.79 & 23.70 & 32.41 & 30.17 & 27.05 & 23.90 & 23.41 & 23.57 & 23.70 & 24.72 \\
\hline
\end{tabular}

* Averages significantly different from the complete treatment, in the same column, by the Dunnett's test $(\mathrm{p}<0.05)$. 
that by Viégas et al. (2009), who obtained a Mg leaf content of $2.2 \mathrm{~g} \mathrm{~kg}^{-1}$ in the complete treatment, and close to that obtained by Haag et al. (1992) $\left(3.5 \mathrm{~g} \mathrm{~kg}^{-1}\right)$. Also, the liming process may have caused the levels of $\mathrm{Mg}$ to average $40 \%$ greater than the complete treatment, in the treatments with individual omission of $\mathrm{N}, \mathrm{K}, \mathrm{Ca}, \mathrm{S}$ and $\mathrm{Cu}$. Only the treatment with the simultaneous omission of $\mathrm{Mg}$ and liming (Mg/-lime) had a lower content than the complete treatment with statistical significance $(-63 \%)$.

Sulphur was less absorbed with the omission of $\mathrm{N}, \mathrm{Mg}, \mathrm{Mg}$--lime, $\mathrm{Cu}, \mathrm{Mn}$ and $\mathrm{Zn}$, especially the latter, which limited the absorption of $\mathrm{S}$ by leaves by $59.2 \%$, even exceeding the absorbance restriction of the control.

The contents of $\mathrm{Cu}, \mathrm{Zn}$ and $\mathrm{Mn}$ were lower than the complete treatment for the majority of individual omission treatments. This may also be attributed to liming, since the increase of soil $\mathrm{pH}$ decreases the availability of micronutrients, thereby affecting their absorption by plants (Malavolta 2006). In this regard, the omission of $\mathrm{Ca} /$-lime increased the absorption of $\mathrm{Cu}$ by $23.7 \%$ and $\mathrm{Zn}$ by $26.15 \%$, and the omission of Mg/-lime increased the content of Mn by $9.7 \%$, relatively to the control. Viégas et al. (2009) considered Mn the most limiting micronutrient for assai palms growth on mediumtextured Ferralsol, corroborating the present study and the importance of $\mathrm{Mn}$ as the most absorbed micronutrient.

The content of B in the complete treatment was $54.24 \mathrm{mg} \mathrm{kg}^{-1}$, which is similar to the $51 \mathrm{mg} \mathrm{kg}^{-1}$ obtained by Haag et al. (1992) and higher than the $31.34 \mathrm{mg} \mathrm{kg}^{-1}$ observed by Viégas et al. (2009), with their complete treatments.

The content of B decreased by $68.17 \%$ with the omission of the nutrient itself, while in the control it decreased by $41 \%$, if compared to the complete treatment. The absorption of B was favored by $23.09 \%$, with the omission of K. Viégas et al. (2004), studying the effect of doses of B on the growth of assai palm plants, concluded that the estimated optimum dose was $2.3 \mathrm{mg} \mathrm{L}^{-1}$, and that at doses higher than $2.5 \mathrm{mg} \mathrm{L}^{-1}$ of $\mathrm{B}$, there was a negative effect on growth. Other studies have identified B as limiting to the development of Amazonian palms (Viégas 1993, Lins 2000, Viégas et al. 2009), but the present study does not corroborate this, as also observed by Haag et al. (1992).
The decreasing order of total nutrient accumulation in leaves, relatively to the complete treatment, was $\mathrm{N}>\mathrm{K}>\mathrm{S}>\mathrm{Ca}>\mathrm{Mg}>\mathrm{P}>\mathrm{Mn}>$ $\mathrm{Zn}>\mathrm{B}>\mathrm{Cu}$ (Table 3), showing that the nutrients most required by assai palms of the studied variety are $\mathrm{N}, \mathrm{K}$ and $\mathrm{S}$.

Viégas et al. (2009), who cultivated the assai palm BRS Pará cultivar on Ferralsol, showed the following decreasing order of macronutrients: $\mathrm{N}>\mathrm{Ca}>$ $\mathrm{K}>\mathrm{Mg}>\mathrm{S}>\mathrm{P}$. For the peach palm, an Amazonian plant of the same botanical family, Fernandes et al. (2013) found the decreasing order of macronutrient accumulation to be $\mathrm{N}>\mathrm{K}>\mathrm{Ca}>\mathrm{P}>\mathrm{Mg}>\mathrm{S}>\mathrm{Na}$. These data reveal that $\mathrm{N}$ and $\mathrm{K}$ are the nutrients most accumulated in the initial phase of development not only for assai palm, but also for other plants from the Arecaceae family. But a discordance, regarding the accumulation of S, remains, since, in the present study, it was the third most required macronutrient, whereas Viégas et al. (2009) and Fernandes et al. (2013) found it to be the fifth and sixth, respectively.

\section{CONCLUSIONS}

1. The initial growth of assai palm plants in sandytextured Ferralsol is limited, on average, by $22 \%$, by the omission of the nutrients N, P, K, $\mathrm{Ca}, \mathrm{Mg}$ and $\mathrm{Cu}$;

2. The leaf dry mass production by assai palm is affected in a descending order by the omission of $\mathrm{P}>\mathrm{Cu}>\mathrm{N}>\mathrm{K}>\mathrm{Mg}$, at an average of $31.9 \%$. Leaf area is restricted by the omission of the individual nutrients $\mathrm{Ca}>\mathrm{N}>\mathrm{P}>\mathrm{K}>\mathrm{Mg}>\mathrm{Zn}$;

3. The plant development measured by the shoot relative growth is affected by the lack of $\mathrm{Ca}>$ $\mathrm{P}>\mathrm{N}>\mathrm{Mg}>\mathrm{Cu}>\mathrm{K}$, with an average reduction of $31 \%$;

4. The nutrients most required by the assai palm BRS Ver-o-Peso cultivar, as evidenced by the levels of nutrients accumulation in leaf dry mass, follow the $\operatorname{order} \mathrm{N}>\mathrm{K}>\mathrm{S}>\mathrm{Ca}>\mathrm{Mg}>\mathrm{P}>\mathrm{Mn}>\mathrm{Zn}>\mathrm{B}>\mathrm{Cu}$.

\section{ACKNOWLEDGMENTS}

The authors thank the Postgraduate Program in Agrarian Sciences of the Universidade Federal Rural da Amazônia; Conselho Nacional de Desenvolvimento Científico e Tecnológico (CNPq), for the scholarship granted to the first author; and Nelson Cruz de Oliveira, for helping in the experiment. 


\section{REFERENCES}

ALMEIDA, S. S.; AMARAL, D. D.; SILVA, A. S. L. Análise florística e estrutura de florestas de Várzea no estuário amazônico. Acta Amazonica, v. 34, n. 4, p. 513$524,2004$.

ARMENGUAD, P. et al. Multilevel analysis of primary metabolism provides new insights into the role of potassium nutrition for glycolysis and nitrogen assimilation in Arabidopsis roots. Plant Physiology, v. 150, n. 2, p. 772$785,2009$.

BOVI, M. L. A.; GODOY, J. R. G.; SPIERING, S. H. Respostas de crescimento de pupunheira à adubação NPK. Scientia Agricola, v. 59, n. 1, p. 161-166, 2002.

ClEMENT, C. R.; BOVI, M. L. A. Padronização de medidas de crescimento e produção em experimentos com pupunheira para palmito. Acta Amazonica, v. 30, n. 3, p. 349-362, 2000.

CRAVO, M. S.; VIÉGAS, I. J. M.; BRASIL, E. C. Recomendações de adubação e calagem para o Estado do Pará. Belém: Embrapa Amazônia Oriental, 2010.

CUNHA, A. C. M. et al. Papel da nutrição mineral na formação de raízes adventícias em plantas lenhosas. Pesquisa Florestal Brasileira, v. 58, n. 1, p. 35-47, 2009.

EMPRESA BRASILEIRA DE PESQUISA AGROPECUÁRIA (Embrapa). Manual de métodos de análise de solo. 2. ed. Rio de Janeiro: Embrapa-CNPS, 1997.

EMPRESA BRASILEIRA DE PESQUISA AGROPECUÁRIA (Embrapa). Métodos de análises bromatológicas de alimentos: métodos físicos, químicos e bromatológicos. Pelotas: Embrapa Clima Temperado, 2010.

EMPRESA BRASILEIRA DE PESQUISA AGROPECUÁRIA (Embrapa). Sistema brasileiro de classificação de solos. Brasília, DF: Embrapa Solos, 2013.

FERNANDES, A. R.; MATOS, G. S. B.; CARVALHO, J. G. Deficiências nutricionais de macronutrientes e sódio em mudas de pupunheira. Revista Brasileira de Fruticultura, v. 35, n. 4, p. 1178-1189, 2013.

FOOD AND AGRICULTURE ORGANIZATION OF THE UNITED NATIONS (FAO). International soil classification system for naming soils and creating legends for soil maps. Rome: FAO, 2015.

GONÇALVES, A. S. Crescimento, composição mineral e sintomas visuais de deficiencias de macronutrientes $e$ boro, em plantas de açaizeiro (Euterpe oleracea Mart.). 2004. 88 f. Dissertação (Mestrado em Agronomia) Universidade Federal Rural da Amazônia, Belém, 2004.
HAAG, H. P.; SILVA FILHO, N. L.; CARMELLO, Q. A. C. Carência de macronutrientes e de boro em plantas de açaí (Euterpe oleracea Mart.). In: CONGRESSO NACIONAL SOBRE ESSÊNCIAS NATIVAS, 2., 1992, São Paulo. Anais... São Paulo: Unipress, 1992. v. 1, p. 477-479.

HAWKESFORD, M. J. Plant response to sulphur deficiency and the genetic manipulation of sulphate transporters to improve S-utilization efficiency. Journal of Experimental Botany, v. 51, n. 1, p. 131-138, 2000.

INSTITUTO BRASILEIRO DE GEOGRAFIA E ESTATÍSTICA (IBGE). Levantamento sistemático da produção agrícola paraense (LSPA/IBGE). Belém: IBGE, 2015.

LAVIOLA, B. G.; DIAS, L. A. S. Teor e acúmulo de nutrientes em folhas e frutos de pinhão-manso. Revista Brasileira de Ciência do Solo, v. 32, n. 5, p. 1969-1975, 2008.

LINS, P. Resposta do coqueiro (Cocos nucifera L.) à aplicação de $\mathrm{N}, \mathrm{P}$, K e Mg nas condições edafoclimáticas de Moju - PA. 2000. 89 f. Dissertação (Mestrado em Agronomia) - Faculdade de Ciências Agrárias do Pará, Belém, 2000.

LOPES, M. L. B. Mercado e distribuição dos retornos sociais do manejo do açaí para produção de frutos. 2001. 73 f. Dissertação (Mestrado em Economia) - Universidade da Amazônia, Belém, 2001.

MALAVOLTA, E. Elementos de nutrição mineral de plantas. São Paulo: Agronômica Ceres, 1980.

MALAVOLTA, E. Manual de nutrição de plantas. São Paulo: Agronômica Ceres, 2006.

MALAVOLTA, E.; VITTI, G. C.; OliveIRA, S. A. Avaliação do estado nutricional das plantas: princípios e aplicações. Piracicaba: Potafos, 1997.

MENEZES, E. M. S.; TORRES, A. T.; SRUR, A. U. S. Valor nutricional da polpa de açaí (Euterpe oleracea Mart) liofilizada. Acta Amazonica, v. 38, n. 2, p. 311-316. 2008.

MIRANDA, R. S. et al. Deficiência nutricional em plântulas de feijão-de-corda decorrente da omissão de macro e micronutrientes. Revista Ciência Agronômica, v. 41, n. 3, p. 326-333, 2010.

OLIVEIRA, M. S. P. et al. Cultivo do açaizeiro para produção de frutos. Belém: Embrapa Amazônia Oriental, 2002. (Circular técnica, 26).

OLIVEIRA, M. S. P.; FARIAS NETO, J. T.; PENA, R. S. Açaí: técnicas de cultivo e processamento. Fortaleza: Instituto Frutal, 2007.

PRADO, R. M.; ROMUALDO, L. M.; ROZANE, D. E. Omissão de macronutrientes no desenvolvimento e no 
estado nutricional de plantas de sorgo (cv. BRS 3010) cultivadas em solução nutritiva. Cientifica, v. 35 , n. 2 , p. 122-128, 2007.

TAIZ, L.; ZEIGER, E. Plant physiology. 4. ed. Porto Alegre: Artmed, 2013.

VIÉGAS, I. J. M. Crescimento do dendezeiro (Elaeis guineensis, Jacq.), concentração, conteúdo e exportação de nutrientes nas diferentes partes de plantas com 2 a 8 anos de idade, cultivadas em Latossolo Amarelo distrófico; Tailândia, Pará. 1993. 217 f. Tese (Doutorado em Agronomia) - Escola Superior de Agricultura Luiz de Queiroz, Universidade de São Paulo, Piracicaba, 1993.
VIÉGAS, I. J. M. et al. Avaliação da fertilidade de um Latossolo Amarelo textura média para o cultivo do açaizeiro no Estado do Pará. Revista de Ciências Agrárias, v. 52, n. 1, p. 23-35, 2009.

VIÉGAS, I. J. M. et al. Efeitos das omissões de macronutrientes e boro na sintomatologia e crescimento em plantas de açaizeiro (Euterpe oleraceae Mart). Revista de Ciências Agrárias, v. 50, n. 1, p. 129-141, 2008.

VIÉGAS, I. J. M. et al. Limitações nutricionais para o cultivo do açaizeiro em Latossolo Amarelo textura média, Estado do Pará. Revista Brasileira de Fruticultura, v. 26, n. 2, p. 382-384, 2004. 